\title{
CORRELATION OF HUMAN HEIGHT WITH HEAD LENGTH IN INDIAN
} INDIVIDUALS

\author{
Girish Shiv Shankar ${ }^{1}$, Veena Vidya Shankar *2, Shailaja Shetty ${ }^{3}$, Radhika K ${ }^{3}$. \\ ${ }^{1}$ MBBS, $3^{\text {rd }}$ year student, Ramaiah Medical College, Bangalore, Karnataka, India. \\ ${ }^{2}$ MBBS, MD, Associate Professor, Department of Anatomy, Ramaiah Medical College, Bangalore, \\ Karnataka, India.
}

${ }^{3}$ MBBS, MD, Professor \& Head, Department of Anatomy, Ramaiah Medical College, Bangalore, Karnataka, India.

${ }^{4}$ Lecturer cum Statistician, Deparment of Community Medicine, Ramaiah Medical College, Bangalore, Karnataka, India.

\section{ABSTRACT}

Introduction: One of the most important aspects in identifying the personal identity of an individual is stature which is influenced by genetic and environmental factors. Stature exhibits a definite proportional relationship with various parts of the body like head, face, trunk, vertebral column and extremities. Rules of body proportions exhibit consistent ratios among themselves and relative to the total body height and are age, sex and race dependent. They are also of great importance in Fine arts, Anatomy, Anthropology and Forensic medicine

Aims: To study the relationship of human height with head length

Materials and Methods: This is a Cross-sectional study carried out in Ramaiah Medical College, Bangalore in 225 individuals aged between 18 and 25 years of age in and around Bangalore. Descriptive statistics, Pearson's correlation coefficient and Linear regression were employed for the Statistical analysis of the data

Results: The mean head length was found to be $21.43 \pm 0.94 \mathrm{~cm}$ and ranged between 19.39 to $24.74 \mathrm{cms}$. The gender wise comparison revealed that there was no statistically significant difference in mean values of head length in in males and females. It was observed that there was a weak positive correlation between height and mean head length which was statistically significant $(r=0.27, \mathrm{P}<0.001)$.

Conclusion: It was observed in the present study, that there was a weak positive correlation between height and head length in both males and females indicating that head length alone is not a reliable indicator in prediction of stature

KEY WORDS: Head length, stature, correlation, height, anthropometry, glabella, inion.

Address for Correspondence: Dr. Veena Vidya Shankar, Associate Professor, Department of Anatomy, Ramaiah Medical College, Bangalore - 560054, Karnataka, India.

Contact No.: Mobile-9980308735 E-Mail: veena24shankar@gmail.com

\begin{tabular}{|c|c|c|}
\hline \multicolumn{3}{|c|}{ Access this Article online } \\
\hline \multirow{2}{*}{$\begin{array}{l}\text { Quick Response code } \\
\text { DOI: } 10.16965 / \text { ijar.2017.457 }\end{array}$} & \multicolumn{2}{|c|}{$\begin{array}{l}\text { Web site: International Journal of Anatomy and Research } \\
\text { ISSN 2321-4287 } \\
\text { www.ijmhr.org/ijar.htm }\end{array}$} \\
\hline & $\begin{array}{l}\text { Received: } 21 \text { Sep } 2017 \\
\text { Peer Review: } 26 \text { Sep } 2017 \\
\text { Revised: None }\end{array}$ & $\begin{array}{l}\text { Accepted: } 08 \text { Nov } 2017 \\
\text { Published (O): } 01 \text { Dec } 2017 \\
\text { Published (P): } 01 \text { Dec } 2017\end{array}$ \\
\hline
\end{tabular}

\section{INTRODUCTION}

One of the most important aspects in identifying the personal identity of an individual is stature which is influenced by genetic and envi- ronmental factors. Stature exhibits a definite proportional relationship with various parts of the body like head, face, trunk, vertebral column and extremities[1]. 
This finds application in anthropometry where the data can be used for the estimation of variations between different individuals and is used for sizing in garment industry; in forensics for the identification of unknown human remains and in designing of the workplace ergonomically. Anthropometry, the standard tool of physical anthropology throws light on the scientific methods and techniques for estimation of various measurements [2]. Various studies have been conducted to determine stature from percutaneous measurements of different body parts, from bony skull, from radiographic lateral cephalograms of skull and cephalo-facial measurements. Some of them have shown positive correlation while others have failed to do so [1].

Stature of an individual is not constant and may show severe reduction with heavy load carrying by individual. However, the age and repeatability of the load carrying determines the decrease. The stature decreases by $6 \mathrm{~mm}$ per decade after 30 years of age. Rules of body proportions exhibit consistent ratios among themselves and relative to the total body height and are age, sex and race dependent. They are also of great importance in Fine arts, Anatomy, Anthropology and Forensic medicine[2].

The various anthropometric parameters used to study the pattern of growth in children are population specific and variables include age, weight, height, and cephalic variables such as head breadth, head length, head circumference and cephalic index. The nutritional status and environmental factors are key factors in complete expression of the genetic potential for growth[3]. The craniofacial anthropometric measurements guide surgeons in surgical repairs of anomalies associated with the head region [4].

Improvement in nutrition when it is suboptimal produces a parallel increase in height, head circumference and brain size leading to improved neurological development and functioning of brain and higher intelligence [5]. It has been reported that in the last century the brain growth has accelerated to a great extent with a decrease in the age at which adult brain size is attained without alteration in the size of adult brain which is probably responsible for shorter cranial length, accounting for greater growth laterally in Japanese and vertically in Europeans[6.]
AIM: To study the relationship of human height with head length.

\section{MATERIALS AND METHODS}

This is a Cross-sectional study carried out in Ramaiah Medical College, Bangalore in individuals aged between 18 and 25 years of age in and around Bangalore. Based on the previous studies conducted by Dr Parth M Pandya[7], Dr Seema[8] \& Dr Sumita Agarwal[9], the correlation co-efficient varied from 0.3 to 0.5 . Assuming the correlation co-efficient to be around 0.34 with the power of $85 \%$ and alpha error of 5 , sample size was estimated to be 225 .

Inclusion criteria: Individuals aged between 18 and 25 years in and around Bangalore

Exclusion criteria - Individuals with features suggestive of dysmorphic syndromes

Method: The measurements were taken three times and their mean value has been considered. Data so collected has been entered in a master chart in Microsoft ${ }^{\circledR}$ Excel and has been analyzed using the SPSS version 17.0. Informed consent has been taken from all participants. The ethical clearance has been obtained from the institution.

Parameters Studied were: Head length : Head length was measured with a spreading caliper from glabella to the inion. Height: The height of the participant was measured with the wall mounted height measuring device-Stadiometer.

Statistical Methods: Descriptive statistics such as mean and standard deviation has been computed for height and head length. Pearson's correlation coefficient has been used to find the correlation between stature and head length. Mutiple Linear regression has been used to predict height from head length of an individual. $P$ value $<0.05$ has been considered as statistically significant. Data analysis was carried out using SPSS version 18.0.chicago SPSS Inc.

\section{RESULTS}

In this study, the sample size was 225 with 93 males and 132 females. The mean head length was found to be $21.43 \pm 0.94 \mathrm{~cm}$ and ranged between 19.39 to $24.74 \mathrm{cms}$. The gender wise comparison revealed that there was no statistically significant difference in mean values of 
head length in in males and females (Tab. - 1). It was observed that there was a weak positive correlation between height and mean head length which was statistically significant $(r=0.27, P<0.001)$ (Table -2). The correlation of height with head length in males and females also revealed a weak positive correlation which was statistically significant (Table -3)

Table 1: Comparison of mean difference in head length among males and females.

\begin{tabular}{|c|c|c|}
\hline & Males & Females \\
\hline Head length & $21.68 \pm 0.96$ & $21.08 \pm 0.78$ \\
\hline
\end{tabular}

Table2: Correlation of height with head length.

\begin{tabular}{|c|c|c|}
\hline & Correlations & Mean Head length \\
\hline Height & Pearson Correlation & $.276^{* *}$ \\
\hline & P value & $<0.001$ \\
\hline
\end{tabular}

Table 3: Correlation of height with head length in males and females.

\begin{tabular}{|c|c|c|}
\hline Sex & & $\begin{array}{c}\text { Mean Head } \\
\text { Length }\end{array}$ \\
\hline \multirow{2}{*}{ Males } & Pearson Correlation & $.193^{*}$ \\
\cline { 2 - 3 } & P value & 0.026 \\
\hline \multirow{2}{*}{ Females } & Pearson Correlation & $.245^{*}$ \\
\cline { 2 - 3 } & P value & 0.018 \\
\hline
\end{tabular}

\section{DISCUSSION}

Parth M. Pandya et al[7], Seema et al [8] and Jadav et al[10], have reported a definite correlation between head length and height of an

Table 4: Various studies of correlation between head length and height.

\begin{tabular}{|c|c|c|c|c|}
\hline Study & Sample size & Males & Females & Parameters \\
\hline Jadav HR (2004) et al[10] & 727 & 468 & 259 & Height, head length, \\
\hline B Danborno (2007) et al[3] & 374 & 173 & 204 & $\begin{array}{l}\text { Height, weight, head length \& breadth, head } \\
\text { circumference and cephalic index }\end{array}$ \\
\hline Arun Kumar Agnihotri (2011) et al[1] & 150 & 75 & 75 & Height, cephalo - facial dimensions \\
\hline Ese Anibor (2011) et al [4] & 200 & 100 & 100 & $\begin{array}{l}\text { Height, total cranial length, total craniofacial } \\
\text { cranial base width, maximum cranial breadth and } \\
\text { total head circumference, Mouth width, biocular } \\
\text { width, minimum frontal breadth, supraorbital } \\
\text { breadth, }\end{array}$ \\
\hline Seema (2011) et al[8] & 400 & - & - & Height, head length \\
\hline Parth M. Pandya (2012) et al[7] & 500 & 370 & 130 & Height, head length \\
\hline Bansal Hansi (2013) et al[2] & 100 & 50 & 50 & Height, head length \\
\hline Rajani Singh (2013) [11] & 208 & 148 & 61 & Height, head length, breadth and head height \\
\hline Sumita Agarwal(2014) et al [9] & 800 & 400 & 400 & Height, head length and breadth \\
\hline Svetlana et al, $2014[12]$ & $\begin{array}{c}300 \\
\text { foetuses }\end{array}$ & - & - & Height with foetal head parameters \\
\hline Khan MA (2015) et al[13] & 672 & 430 & 242 & $\begin{array}{l}\text { Height, Cranial length and breadth, auricular } \\
\text { cranial length, }\end{array}$ \\
\hline Neetu Purohit (2015) et al[14] & 500 & 291 & 209 & Height, head length and breadth \\
\hline Sudeep Kumar Yadav(2015) et al[15] & 140 & - & - & $\begin{array}{l}\text { Height, head length, facial height, Breadth of the } \\
\text { bizygomatic arch }\end{array}$ \\
\hline Vinitha G et al, 2015[16] & 200 & 100 & 100 & Height, head length \\
\hline Present study(2016) & 225 & 88 & 132 & Height, head length \\
\hline
\end{tabular}


Khan MA et al [13] have shown a statistically significant correlation between the height and cranial length and breadth and auricular cranial length. Neetu Purohit et al[14] results show that two parameters head length and breadth correlated positively with stature except head breadth in females. Sudeep Kumar Yadav et al[15] have reported a statistically significant positive correlation between the height and the other cephalometric variables namely head length, facial height, breadth of the bizygomatic arch. Vinitha $G$ et al [16] have found a strong association between height and head length in both boys and girls.

In the present study, the correlation of height with head length in males and females revealed weak positive correlation which was statistically significant.

\section{CONCLUSION}

It was observed in the present study, that there was a weak positive correlation between height and head length in both males and females indicating that head length alone is not a reliable indicator in prediction of stature

\section{Conflicts of Interests: None}

\section{REFERENCES}

[1]. Arun Kumar Agnihotri, Smita Kachhwaha, Krishna Googoolye, Anishta Allock. Estimation of stature from cephalo-facial dimensions by regression analysis in Indo-Mauritian population. Journal of Forensic and Legal Medicine. 2011;18:167-172.

[2]. Bansal Hansi, Badiye Ashish. An Estimation of Correlation between the Head length and the Stature of the Children aged between 6-10 Years. Research Journal of Forensic Sciences. 2013;1(2):1-5.

[3]. B Danborno, P Nuhu, K Yandev. Relationship between Growth Pattern and Head Dimensions in Nigerian Children (5-15Years). The Internet Journal of Biological Anthropology. 2007; 2(1):1- 6.

[4]. Ese Anibo, Dennis E. O. Eboh and Mabel O. Etetafia. A study of craniofacial parameters and total body height. Advances in Applied Science Research. 2011; $2(6): 400-405$.
[5]. Richard Lynn. The role of nutrition in secular increases in intelligence. Prrwrt. VI\&L id. DIR.1990;II(3):273-285.

[6]. Makiko Kouchi. Secular changes in the Japanese head form viewed from somatometric data. Anthropological Science. 2004;112: 41-52.

[7]. Parth M. Pandya, Suresh P. Rathod, Shamin V. Patel, Shailesh M.Patel, Ankur Z. Zalawadiya, Sapana B.Shah, Jignesh D. Vadgama, Mitesh A. Shah. Correlation and Regression Analysis of Stature In Relation To Head Length in Children. NJIRM 2012;3(3):4346.

[8]. Seema and Mahajan A. Estimation of personal height from the length of head in Punjab zone. International Journal of Plant, Animal and Environmental Sciences. 2011;1(3):205-208.

[9]. Agarwal S, Agarwal SK, Jain SK. Correlation Between the Stature and Cranial Measurements in Population of North India. Acta Medica International. 2014;1(2):99-102.

[10]. Jadav HR, Shah GV. Determination of personal height from the length of head in Gujarat Region. J.Anat.Soc.India. 2004;53 (1):20-21.

[11]. Singh, R. Estimation of stature and age from head dimensions in Indian population. Int. J. Morphol.2013;31(4):1185-1190.

[12]. Svetlana Jovevska, Milka Zdravkovska, Gordana Panova, Nevenka Velickova. Correlation between some anthropometrical parameters of the fetal head. Science \& Technologies. 2014;IV(1):483-486.

[13]. Khan MA, Chaudhry MN, Altaf FMN. Cranial measurements; estimation of stature from cranial measurements. Professional Med J. 2015;22(8):10341038.

[14]. Neetu Purohit, J K Khatri. Dereviation of Regression Equation for the Estimation of Stature from Cranial Dimensions in Western Rajasthan Populations. Sch. J. App. Med. Sci., 2015;3(5B):1903-1905.

[15]. Sudeep Kumar Yadav, Sanosh Ttimalsina, Niraj Pandey, Gopal KC, Dipesh Budhathoki. Correlation of personal height with various cephalometric variables (Head length, Facial height, Bizygomatic arch breadth). International Journal of Innovative and Applied Research. 2015;3(9):5-8.

[16]. Vinitha G, Sampada P Kadadi, Mallikarjun M, Jayprakash B R. Correlation of stature in relation to headlength in children. International Journal of Healthcare Sciences. 2015;2(66-71):71-66.

How to cite this article:

Girish Shiv Shankar, Veena Vidya Shankar, Shailaja Shetty, Radhika K. CORRELATION OF HUMAN HEIGHT WITH HEAD LENGTH IN INDIAN INDIVIDUALS. Int J Anat Res 2017;5(4.3):4723-4726. DOI: 10.16965/ijar.2017.457 